\title{
Dietary glutamine improves the function of erythrocytes through its metabolites in juvenile carp (Cyprinus carpio var. Jian)
}

\author{
Hua-Tao Li ${ }^{\mathrm{a}, \mathrm{e}}$, Wei-Dan Jiang ${ }^{\mathrm{a}, \mathrm{b}, \mathrm{c}}$, Yang Liu ${ }^{\mathrm{a}, \mathrm{b}, \mathrm{c}}$, Jun Jiang ${ }^{\mathrm{a}, \mathrm{b}, \mathrm{c}}$, Yong-An Zhang ${ }^{\mathrm{d}}$, Pei Wu ${ }^{\mathrm{a}, \mathrm{b}, \mathrm{c}}$, \\ Yun-Yun Zeng ${ }^{\mathrm{a}, \mathrm{b}, \mathrm{c}}$, Xiao-Qiu Zhou ${ }^{\mathrm{a}, \mathrm{b}, \mathrm{c}, *}$, Lin Feng ${ }^{\mathrm{a}, \mathrm{b}, \mathrm{c}, *}$ \\ a Animal Nutrition Institute, Sichuan Agricultural University, Sichuan, Chengdu 611130, China \\ ${ }^{\mathrm{b}}$ Fish Nutrition and Safety Production University Key Laboratory of Sichuan Province, Animal Nutrition Institute, Sichuan Agricultural University, Sichuan, Chengdu \\ 611130, China \\ ${ }^{c}$ Key Laboratory for Animal Disease-Resistance Nutrition of Ministry of Education, Sichuan Agricultural University, Sichuan, Chengdu 611130, China \\ ' Institute of Hydrobiology, Chinese Academy of Sciences, Hubei, Wuhan 430072, China \\ e Conservation and Utilization of Fishes Resources in the Upper Reaches of the Yangtze River Key Laboratory of Sichuan Province, College of Life Sciences, Neijiang Normal \\ University, Sichuan, Neijiang 641000, China
}

\section{A R T I C L E I N F O}

\section{Keywords:}

Erythrocyte function

Apoptosis

Glutamine

Alanine

Citrulline

Proline

\begin{abstract}
A B S T R A C T
An 8-week feeding trial was conducted to determine the effect of dietary glutamine (Gln) on the erythrocyte function in juvenile Jian carp. The results indicated that dietary Gln caused significant increases in haematocrit, erythrocyte count, haemoglobin concentration, mean corpuscular volume and mean corpuscular haemoglobin content in carp blood. Dietary Gln caused significant decreases in the levels of superoxide anion, hydrogen peroxide, met-haemoglobin, malonaldehyde and protein carbonyl and increases in the level of reduced glutathione and the activities of $\mathrm{Na}^{+}, \mathrm{K}^{+}$-ATPase and lactate dehydrogenase in carp erythrocytes. These results demonstrated that dietary Gln could improve the function of erythrocytes in fish. Meanwhile, the present study explored the effect of dietary Gln on hydroxyl radical $(\cdot \mathrm{OH})$-induced apoptosis in carp erythrocytes. We found that dietary Gln prevented the $\cdot \mathrm{OH}$-induced apoptosis by inhibiting the generation of reactive oxygen species and the oxidation of cellular components, and restoring the non-enzymatic and enzymatic antioxidant activities in fish erythrocytes. These results revealed that the effects of Gln on the function may be closely associated with apoptosis in fish erythrocytes. Moreover, our data suggested that dietary Gln raised the levels of alanine (Ala), citrulline (Cit) and proline (Pro) in plasma of carp. We then examined the protective effects of Ala, Cit and Pro at the physiological concentrations in $\cdot \mathrm{OH}$-induced carp erythrocytes. The results indicated that Ala, Cit or Pro at the physiological concentrations suppressed apoptosis and the oxidation of cellular components, and restored the GSH antioxidant system in the $\cdot \mathrm{OH}$-induced carp erythrocytes. Moreover, the combination of Ala, Cit and Pro at the physiological concentrations produces a greater protective effect than their individual effects in fish erythrocytes. These results displayed that the effects of Gln on erythrocytes are at least partly dependent on that of its metabolites in fish. Ala, Cit, Pro and their combination could serve as an antioxidant or apoptosis-inhibitor in fish.
\end{abstract}

\section{Introduction}

Erythrocytes play an essential role in transporting $\mathrm{O}_{2}$ and $\mathrm{CO}_{2}$ for respiration in fish (Kulkeaw and Sugiyama, 2012). However, fish erythrocytes may be continuously exposed to both endogenous and exogenous sources of reactive oxygen species (ROS). Studies have demonstrated that erythrocytes continuously produce ROS by the autoxidation of haemoglobin ( $\mathrm{Hb}$ ) in human (Cimen, 2008). ROS released from neutrophils, macrophages and endothelial cells in the vasculature are taken up by erythrocytes (Li et al., 2015). ROS can initiate erythrocytes apoptosis (Cimen, 2008) that can lead to the decrease of respiratory function in human (Lang et al., 2008). Similar to

\footnotetext{
Abbreviations: Cit, citrulline; ROS, reactive oxygen species; PCS, physiological carp saline; Hct, haematocrit; RBC, red blood cell count; HbC, haemoglobin concentration; MCV, mean

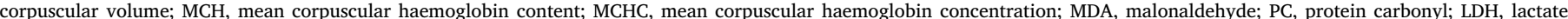

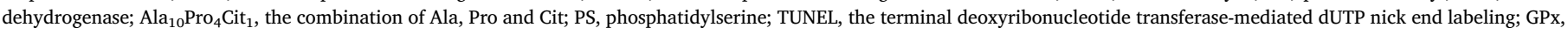
glutathione peroxidase; GSH, reduced glutathione; GR, glutathione reductase; GST, glutathione S-transferase

* Corresponding authors at: Animal Nutrition Institute, Sichuan Agricultural University, Chengdu 611130, Sichuan, China.

E-mail address: zhouxq@sicau.edu.cn (X.-Q. Zhou).
} 
human erythrocytes, fish erythrocytes contain high concentrations of $\mathrm{Hb}$ that can continuously produce ROS (Li et al., 2016a). Moreover, it has been reported that many pollutants initiate the generation of ROS in fish (Sevcikova et al., 2011). Our previous study indicated that ROS triggers apoptosis in fish erythrocytes (Li et al., 2013). So, erythrocytes may continuously suffer ROS-induced apoptosis in fish. The cytosol contains antioxidants that can scavenge ROS in cells (Surai et al., 2016; Wu et al., 2011). However, erythrocytes are very sensitive to ROS due to the high content of poly-unsaturated fatty acid in membrane (Li et al., 2013). The oxidation of lipids and proteins occurs when ROS production exceeds the antioxidant capacity of a cell (Rau et al., 2004). The oxidative products of lipids and proteins play an important role in the induction of apoptosis ( $\mathrm{Li}$ et al., 2016a). So, it is important to expand our knowledge of how to increase the antioxidant status and quench erythrocyte apoptosis in fish.

Glutamine (Gln) is an important dietary nutrient in fish (Lin and Zhou, 2006). Studies suggested that dietary Gln improves the antioxidant status of serum, hepatopancreas and muscles in hybrid sturgeon (Zhu et al., 2011) and of spleen in Jian carp (Hu et al., 2015). Our study indicated that Gln decrease the level of ROS and inhibits oxidation of cellular components and apoptosis in fish erythrocytes in vitro (Li et al., 2013). However, little attention has been given to the effects of Gln on fish erythrocytes in vivo. The beneficial effects of Gln may be closely associated with its metabolites in fish. Studies showed that the small intestine converted the most of Gln in diet and plasma to alanine (Ala), citrulline (Cit) and proline (Pro), which released into the portal circulation in mammals (Li et al., 2016a). Previous studies in our laboratory demonstrated that Ala, Cit and Pro inhibit ROS-induced apoptosis in carp erythrocytes (Li et al., 2013, 2016a). Therefore, the metabolites may be the real antioxidant or apoptosis-inhibitor in Glnsupplementation fish. However, the information regarding the metabolites of Gln in fish and their effects on fish erythrocytes at physiological concentration is scarce.

In this study, we explored the effect of dietary Gln on hematological and hematochemical parameters in carp (Cyprinus carpio var. Jian) and of Ala, Cit, Pro and their combination on hydroxyl radical $(\cdot \mathrm{OH})$ induced apoptosis in carp erythrocytes. $\cdot \mathrm{OH}$ was generated by the Fenton reaction. The purpose was to evaluate the effect of Gln supplementation on the erythrocyte function in fish. The results may provide a basis for applications of Gln as antioxidant or apoptosisinhibitor and reveal its underlying mechanisms in fish.

\section{Materials and methods}

\subsection{Chemicals}

Heparin sodium ( $\geq 99 \%$ ), L-glutamine, L-alanine, L-citrulline and proline were purchased from Sigma-Aldrich Co., LLC (St. Louis, MO, USA). Aqueous solutions of hydrogen peroxide $\left(\mathrm{H}_{2} \mathrm{O}_{2}\right)(30 \%)$ and $\mathrm{FeSO}_{4}$ (analytical grade) were purchased from the Shanghai Chemical Reagent Factory (Shanghai, China). The paraformaldehyde and Triton X-100 were purchased from Nanjing KeyGEN Biotech. Co., Ltd. (Nanjing, Jiangsu, China). Physiological carp saline (PCS) which contained (in mmol L ${ }^{-1}$ ) NaCl, 141.10; KC1, 1.43; $\mathrm{CaCl}_{2}, 0.99 ; \mathrm{NaHCO}_{3}, 2.64$; and glucose, 6.16, modified to give a total osmolarity of $280 \mathrm{mosm} \mathrm{L}^{-1}$ and $\mathrm{pH} 7.9$ was prepared in our laboratory. All other chemicals were analytical grade.

\subsection{Animal experiment}

\subsubsection{Animal collection and acclimation conditions}

Juvenile Jian carp were purchased from the Ya'an fisheries (Sichuan, China) and acclimated to the experimental conditions as described by Jiang et al. (2011). Before starting the experiment, the fish were fed to satiation with a commercial diet in a closed water and oxygen auto-supplemented system. Water change rates in the system were maintained at $1.2 \mathrm{~L} / \mathrm{min}$ and the water was drained through biofilters to remove solid substances and reduce ammonia concentration. The diurnal cycle was 12 -h light/12-h dark. The water temperature varied between 23 and $26^{\circ} \mathrm{C}$.

\subsubsection{Diet preparation and feed}

Two experimental diets were formulated as described in our previous study (Lin and Zhou, 2006). The basal diet contained $350.0 \mathrm{~g}$ crude protein $/ \mathrm{kg}$ diet and $56.3 \mathrm{~g}$ crude lipid $/ \mathrm{kg}$ diet. In Gln diet, Gln premix was added to the basal diet to provide $12.3 \mathrm{~g} \mathrm{Gln} / \mathrm{kg}$ diet, which was the required Gln concentration for optimal growth established by the previous study, and the amount of cellulose was reduced to compensate. Procedures for diet preparation and storage $\left(-20^{\circ} \mathrm{C}\right)$ were the same as those described by Shiau and Su (2005). The concentration of Gln in the experimental diets was determined spectrophotometrically as described by Jiang et al. (2009).

The procedures of feeding trail were based on those described by Lin and Zhou (2006) with slight modifications. A total of 400 fish (average initial weight $6.08 \pm 0.03 \mathrm{~g}$ ) from the acclimatization aquarium were randomly distributed into 2 groups of 4 replicates each. The groups were fed either the basal diet (basal group) or the Gln diet (Gln group) for 56 days in the experimental aquariums $(90 \mathrm{~cm} \times 30 \mathrm{~cm} \times 40 \mathrm{~cm})$.

\subsubsection{Sample collection and analysis}

At the end of the feeding trial the fish in each aquarium were counted and weighed by the means of Lin and Zhou (2006). Data on initial number, final number, initial weight and final weight of fish were used to calculate survival rate and weight gain. The blood (approximately $1 \mathrm{~mL}$ ) from 20 fish of each group was drawn into a syringe via caudal puncture, respectively. Within $1 \mathrm{~h}$, the blood was centrifuged at $1000 \times g$ and $4{ }^{\circ} \mathrm{C}$ for $3 \mathrm{~min}$. The plasma and erythrocytes were isolated for measurements of hematological and hematochemical indices and cell experiment. The haematocrit (Hct), erythrocyte (red blood cell) count (RBC) and haemoglobin concentration (HbC) in the blood were determined by the means of Speckner et al. (1989). From these data, the following variables were calculated: Mean corpuscular volume $(\mathrm{MCV})=\mathrm{Hct} / \mathrm{RBC}$ (fl/cell); Mean corpuscular haemoglobin content $(\mathrm{MCH})=\mathrm{HbC} / \mathrm{RBC}(\mathrm{pg} / \mathrm{cell})$; Mean corpuscular haemoglobin concentration $(\mathrm{MCHC})=\mathrm{HbC} / \mathrm{Hct}(\mathrm{g} / \mathrm{l})$. Free amino acid concentrations in plasma were determined using automatic amino acid analyzer (L-8900, Hitachi, Japan) as described by Zhou et al. (2011). The levels of superoxide anion $\left(\mathrm{O}_{2} \cdot{ }^{-}\right), \mathrm{H}_{2} \mathrm{O}_{2}$, met-haemoglobin (Met$\mathrm{Hb}$ ), malonaldehyde (MDA), protein carbonyl (PC) and reduced glutathione (GSH) and the activities of lactate dehydrogenase (LDH) and $\mathrm{Na}^{+}, \mathrm{K}^{+}$-ATPase were also measured in the erythrocytes at the same time. Six replicates were prepared for each treatment.

\subsection{Cell experiment}

\subsubsection{Erythrocyte isolation}

The isolation of erythrocyte from the basal group and Gln group was performed as those described by Li et al. (2013). The isolated erythrocytes were resuspended in PCS at a final concentration of $1 \%$ $(\mathrm{v} / \mathrm{v})$ and used in following experiments.

All procedures above were approved by the Institutional Animal Care and Use Committee of Sichuan Agricultural University in accordance with the Institutional Ethics Committee of the Chinese Institute of Chemical Biology guidelines.

\subsubsection{Induction of apoptosis}

Apoptosis was induced according to the methods of Li et al. (2016a), with slight modifications. A suspension ( $1 \% \mathrm{v} / \mathrm{v})$ of erythrocytes from the basal group or Gln group was exposed to $\mathrm{FeSO}_{4} / \mathrm{H}_{2} \mathrm{O}_{2}$ at a final concentration of $40 \mu \mathrm{M} / 20 \mu \mathrm{M}$. Another suspension (1\% v/v) of erythrocytes from the basal group was treated with PCS only. After incubation at $37^{\circ} \mathrm{C}$ for $9 \mathrm{~h}$, the samples were centrifuged $(3 \mathrm{~min}$ at 
$1000 \times g, 4^{\circ} \mathrm{C}$ ), and the erythrocytes were collected for determination of the concentration of $\mathrm{O}_{2} \cdot{ }^{-}, \mathrm{H}_{2} \mathrm{O}_{2}, \mathrm{MDA}, \mathrm{PC}$ and GSH, the activities of superoxide dismutase (SOD), catalase (CAT) and glutathione peroxidase (GPx), phosphatidylserine (PS) exposure and DNA fragmentation. The experiment was performed with 4 replicates in per treatment.

\subsubsection{Cytoprotection assays}

To investigate the effects of Ala, Pro and Cit at physiological concentration on fish erythrocytes, the experiment was carried out as the method described by Li et al. (2016a, 2016b). Ala, Cit and Pro were combined in the molar ratio 10:4:1 $\left(\mathrm{Ala}_{10} \mathrm{Pro}_{4} \mathrm{Cit}_{1}\right)$ for investigating the effects of their mixture. The isolated erythrocytes from carp in the basal group were suspended in PCS (control) and PCS containing 0.00, 0.175, $0.35,0.70$ or $1.40 \mathrm{mM}$ of Ala, Cit, Pro or $\mathrm{Ala}_{10} \mathrm{Pro}_{4} \mathrm{Cit}_{1}$ at a $1 \%$ haematocrit, respectively. All erythrocyte suspensions above were pre-incubated at $37^{\circ} \mathrm{C}$ for $1.5 \mathrm{~h}$. $\mathrm{FeSO}_{4} / \mathrm{H}_{2} \mathrm{O}_{2}$ was then added at a final concentration of $40 \mu \mathrm{M} / 20 \mu \mathrm{M}$ for the induction of apoptosis, except in the control. After incubation at $37^{\circ} \mathrm{C}$ for $9 \mathrm{~h}$, the erythrocytes were collected for measuring the levels of Met-Hb, MDA, PC and GSH, the activities of glutathione reductase (GR) and glutathione S-transferase (GST), PS exposure and DNA fragmentation. The experiment was performed with 4 replicates per treatment and the control.

\subsection{Analysis and measurement}

\subsubsection{Biochemical analysis}

The activities of LDH and $\mathrm{Na}^{+}, \mathrm{K}^{+}$-ATPase were measured according to Chen et al. (2009). The concentrations of $\mathrm{O}_{2}{ }^{-}$and MDA and The activity of SOD in the erythrocytes were measured as described by Lin et al. (2011). The levels of $\mathrm{H}_{2} \mathrm{O}_{2}$, Met-Hb and PC in the erythrocytes were determined according to the method described by Li et al. (2013). The activity of GPx was determined by the method of Wang et al. (2012). The content of GSH and the activities of CAT and GR were measured according to the method described by Li et al. (2014). The activity of GST was assayed using the method described by Kaptaner et al. (2009). Protein concentration was determined by the method of Darbkin (1946 ).

\subsubsection{Measurement of apoptosis}

The PS exposure and DNA fragmentation in fish erythrocytes were respectively assessed by the Annexin V-FITC Apoptosis Detection Kit and TdT-mediated dUTP nick end labeling (TUNEL) Apoptosis Assay Kit (Beyotime, Nantong, China) as described previously (Li et al., 2016a, 2016b).

\subsection{Statistical analysis}

Data were expressed as mean \pm standard deviation (S.D.). The data were subjected to one-way analysis of variance (ANOVA). Duncan's multiple range tests was used to determine significant differences. A $t$-test was used for comparisons between two groups. The $50 \%$ and $5 \%$ inhibitory dose $\left(\mathrm{ID}_{50}\right.$ and $\left.\mathrm{ID}_{5}\right)$ was obtained by the probit analysis. The significance level adopted was $95 \%(\alpha=0.05)$. All statistical analyses were performed using the SPSS 13.0 for Window (Chicago, IL, USA).

\section{Results}

\subsection{The effects of dietary Gln on hematological and hematochemical index in carp}

As presented in Table 1, dietary Gln supplements administered for 56 days significantly increased the growth of carp when compared with the basal group $(P<0.05)$ (Table 1$)$, which agreed with our previous study (Lin and Zhou, 2006). No mortality was observed in the basal group and Gln group (Table 1). The levels of Ala, Cit and Pro in plasma
Table 1

Growth performance, survival rate and the levels of Ala, Cit and Pro in plasma of Jian carp fed diets containing Gln for 56 days.

\begin{tabular}{ccc}
\hline & Basal group & Gln group \\
\hline Initial weight $(\mathrm{g} /$ fish) & $6.08 \pm 0.01^{\mathrm{a}}$ & $6.09 \pm 0.03^{\mathrm{a}}$ \\
Final weight $(\mathrm{g} / \mathrm{fish})$ & $49.38 \pm 1.68^{\mathrm{a}}$ & $62.28 \pm 2.17^{\mathrm{b}}$ \\
Weight gain $(\mathrm{g} / \mathrm{fish})$ & $43.30 \pm 1.69^{\mathrm{a}}$ & $56.19 \pm 2.16^{\mathrm{b}}$ \\
Survival rate $(\%)$ & $100.00 \pm 0.00^{\mathrm{a}}$ & $100.00 \pm 0.00^{\mathrm{a}}$ \\
Ala $(\mu \mathrm{M})$ & $810.97 \pm 57.52^{\mathrm{a}}$ & $857.01 \pm 74.27^{\mathrm{b}}$ \\
Cit $(\mu \mathrm{M})$ & $98.32 \pm 7.78^{\mathrm{a}}$ & $109.45 \pm 1.15^{\mathrm{b}}$ \\
Pro $(\mu \mathrm{M})$ & $518.06 \pm 86.09^{\mathrm{a}}$ & $557.61 \pm 92.85^{\mathrm{b}}$ \\
\hline
\end{tabular}

Values are means \pm S.D. $(n=6)$. Values within the same line having different superscripts are significantly different $(P<0.05)$.

Table 2

The haematocrit (Hct), erythrocyte (red blood cell) count (RBC), haemoglobin concentration ( $\mathrm{HbC}$ ), mean corpuscular volume (MCV), and mean corpuscular haemoglobin content $(\mathrm{MCH})$ and mean corpuscular haemoglobin concentration (MCHC) in blood of Jian carp fed diets containing Gln for 56 days.

\begin{tabular}{ccc}
\hline & Basal group & Gln group \\
\hline Hct (\%) & $0.39 \pm 0.01^{\mathrm{a}}$ & $0.47 \pm 0.01^{\mathrm{b}}$ \\
RBC $\left(10^{12} \mathrm{~L}^{-1}\right)$ & $2.15 \pm 0.05^{\mathrm{a}}$ & $2.42 \pm 0.06^{\mathrm{b}}$ \\
HbC $\left(\mathrm{g} \mathrm{L}^{-1}\right)$ & $88.29 \pm 2.02^{\mathrm{a}}$ & $107.64 \pm 2.45^{\mathrm{b}}$ \\
MCV (fL cell & $181.34 \pm 3.80^{\mathrm{a}}$ & $194.28 \pm 5.04^{\mathrm{b}}$ \\
MCH (pg cell & $41.06 \pm 1.47^{\mathrm{a}}$ & $44.51 \pm 1.93^{\mathrm{b}}$ \\
MCHC $\left(\mathrm{g} \mathrm{L}^{-1}\right)$ & $226.38 \pm 5.18^{\mathrm{a}}$ & $229.02 \pm 5.22^{\mathrm{a}}$ \\
\hline
\end{tabular}

Values are means \pm S.D. $(n=6)$. Values within the same line having different superscripts are significantly different $(P<0.05)$

of Gln group were respectively estimated to be $857.01,109.45$ and $557.61 \mu \mathrm{M}$ that are more than that in basal group $(P<0.05)$ (Table 1$)$.

The effects of Gln on Hct, RBC, HbC, MCV, MCH and MCHC in blood of juvenile Jian carp are presented in Table 2. Dietary Gln caused significant increases in Hct, RBC, HbC, MCV and MCH when compared with the basal group $(P<0.05)$ (Table 2$)$. MCHC in blood of juvenile Jian carp was not significantly affected by the treatments $(P>0.05)$ (Table 2).

The effects of Gln on the levels of $\mathrm{O}_{2} \cdot{ }^{-}, \mathrm{H}_{2} \mathrm{O}_{2}$, Met-Hb, MDA, PC and GSH and the activities of $\mathrm{Na}^{+}, \mathrm{K}^{+}$-ATPase and LDH in the erythrocytes of juvenile Jian carp are shown in Table 3. Compared with the basal group, dietary Gln caused significant decreases in the levels of $\mathrm{O}_{2} \cdot{ }^{-}, \mathrm{H}_{2} \mathrm{O}_{2}$, Met-Hb, MDA and PC and increases in the level of GSH and the activities of $\mathrm{Na}^{+}, \mathrm{K}^{+}$-ATPase and LDH $(P<0.05)$ (Table 3).

\subsection{The effects of dietary $\mathrm{Gln}$ on the $\cdot \mathrm{OH}$-treated erythrocytes of carp}

As shown in Fig. 1, exposure to $\cdot \mathrm{OH}$ significantly increased the

Table 3

The levels of superoxide anion $\left(\mathrm{O}_{2} \cdot{ }^{-}\right)$, hydrogen peroxide $\left(\mathrm{H}_{2} \mathrm{O}_{2}\right)$, met-haemoglobin (Met-Hb), malondialdehyde (MDA), protein carbonyl (PC) and reduced glutathione (GSH) and the activities of lactate dehydrogenase (LDH) and $\mathrm{Na}^{+}, \mathrm{K}^{+}$-ATPase in the erythrocytes of Jian carp fed diets containing Gln for 56 days.

\begin{tabular}{|c|c|c|}
\hline & Basal group & Gln group \\
\hline $\mathrm{O}_{2} \cdot{ }^{-}\left(\mathrm{U} \mathrm{g}^{-1}\right.$ protein $)$ & $27.39 \pm 1.63^{\mathrm{b}}$ & $21.37 \pm 1.43^{\mathrm{a}}$ \\
\hline $\mathrm{H}_{2} \mathrm{O}_{2}\left(\mu \mathrm{mol} \mathrm{g}{ }^{-1}\right.$ protein $)$ & $41.15 \pm 2.52^{\mathrm{b}}$ & $33.71 \pm 2.28^{\mathrm{a}}$ \\
\hline Met-Hb $\left(\mathrm{g} \mathrm{L}^{-1}\right)$ & $1.73 \pm 0.09^{\mathrm{b}}$ & $1.41 \pm 0.08^{\mathrm{a}}$ \\
\hline MDA (nmol $\mathrm{mg}^{-1}$ protein) & $2.24 \pm 0.12^{\mathrm{b}}$ & $1.80 \pm 0.12^{\mathrm{a}}$ \\
\hline PC (nmol mg ${ }^{-1}$ protein) & $1.12 \pm 0.06^{\mathrm{b}}$ & $0.87 \pm 0.06^{\mathrm{a}}$ \\
\hline $\mathrm{GSH}\left(\mu \mathrm{mol} \mathrm{g}{ }^{-1}\right.$ protein) & $5.35 \pm 0.32^{\mathrm{a}}$ & $6.01 \pm 0.19^{b}$ \\
\hline LDH (U mg ${ }^{-1}$ protein) & $121.26 \pm 6.18^{\mathrm{a}}$ & $146.78 \pm 7.98^{b}$ \\
\hline $\mathrm{Na}^{+}, \mathrm{K}^{+}$-ATPase $\left(\mathrm{U} \mathrm{mg}^{-1}\right.$ protein) & $1.51 \pm 0.07^{\mathrm{a}}$ & $1.86 \pm 0.10^{\mathrm{b}}$ \\
\hline
\end{tabular}

Values are means \pm S.D. $(n=6)$. Values within the same line having different superscripts are significantly different $(P<0.05)$. 


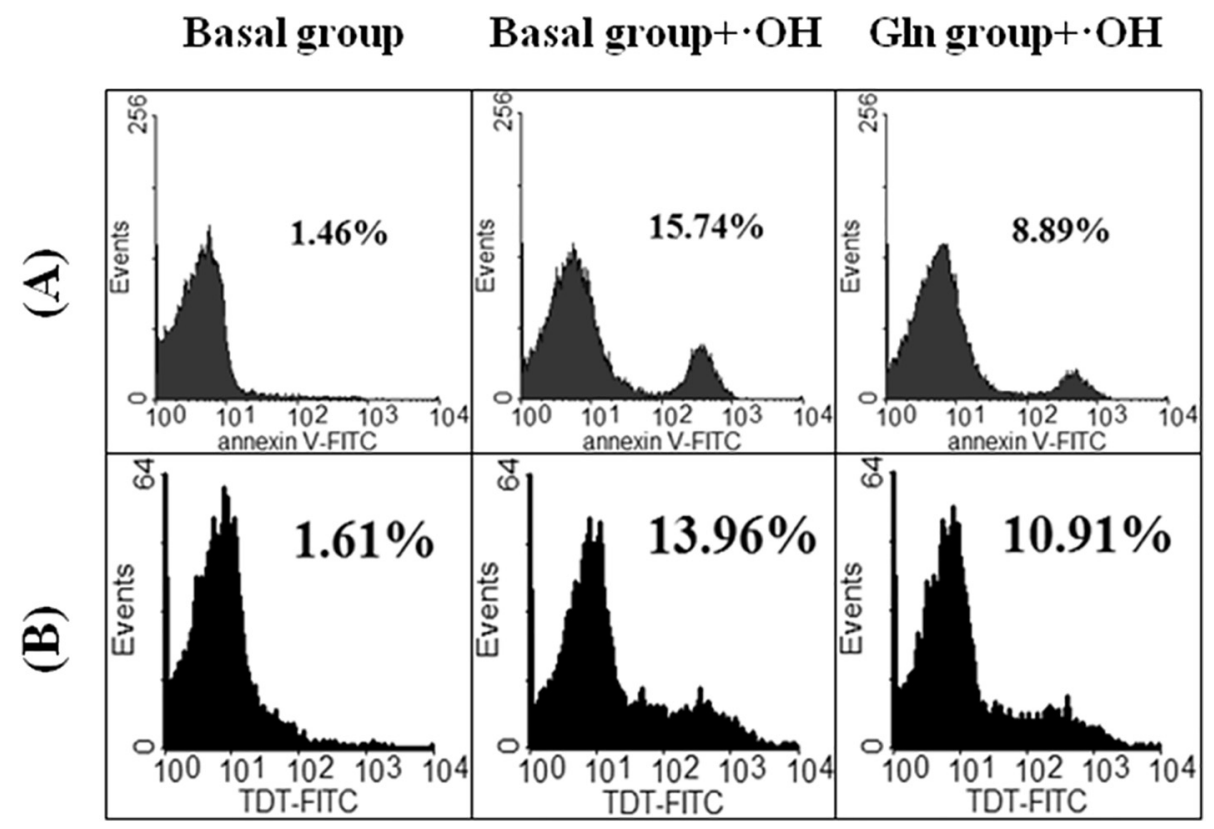

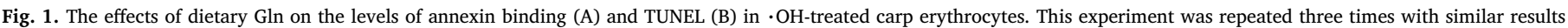
achieved.

levels of annexin binding and TUNEL-positive cells in erythrocytes of carp in the basal group relative to those in the untreated basal group $(P<0.05)$, which suggested that $\cdot \mathrm{OH}$ induces an increase in the PS exposure and DNA fragmentation in the basal group. However, the levels of annexin binding and TUNEL-positive cells in $\cdot$ OH-treated erythrocytes of carp in the Gln group was lower than that in the basal group $(P<0.05)$ (Fig. 1$)$, which indicated that dietary Gln effectively protects erythrocytes from $\cdot \mathrm{OH}$-induced PS exposure and DNA fragmentation in carp.

The effects of dietary Gln on $\mathrm{O}_{2} \cdot{ }^{-}, \mathrm{H}_{2} \mathrm{O}_{2}$, MDA and PC in $\cdot \mathrm{OH}-$ treated erythrocytes of carp are presented in Table 4. Compared with the untreated basal group, exposure to $\cdot \mathrm{OH}$ significantly increased the levels of $\mathrm{O}_{2} \cdot{ }^{-}, \mathrm{H}_{2} \mathrm{O}_{2}$, MDA and PC in the erythrocytes of the basal group $(P<0.05)$. However, $\mathrm{O}_{2} \cdot{ }^{-}, \mathrm{H}_{2} \mathrm{O}_{2}$, MDA and PC levels in $\cdot \mathrm{OH}-$ treated erythrocytes of carp in the Gln group was lower than that in the basal group $(P<0.05)$ (Table 4$)$, which indicated that dietary Gln effectively prevented the $\cdot \mathrm{OH}$-induced increase in the levels of $\mathrm{O}_{2} \cdot{ }^{-}$,

Table 4

The levels of superoxide anion $\left(\mathrm{O}_{2} \cdot{ }^{-}\right)$, hydrogen peroxide $\left(\mathrm{H}_{2} \mathrm{O}_{2}\right)$, Malondialdehyde (MDA), protein carbonyl (PC) and reduced glutathione (GSH) and the activities of superoxide dismutase (SOD), catalase (CAT) and glutathione peroxidase (GPx) in the . $\mathrm{OH}$-treated erythrocytes from juvenile Jian carp fed diets containing Gln for 56 days.

\begin{tabular}{|c|c|c|c|}
\hline & Basal group & Basal group $+\cdot \mathrm{OH}$ & Gln group $+\cdot \mathrm{OH}$ \\
\hline $\begin{array}{c}\mathrm{O}_{2} \cdot{ }^{-}\left(\mathrm{U} \mathrm{g}^{-1}\right. \\
\text { protein })\end{array}$ & $26.74 \pm 1.88^{\mathrm{a}}$ & $61.78 \pm 4.22^{\mathrm{c}}$ & $47.78 \pm 2.68^{\mathrm{b}}$ \\
\hline $\begin{array}{c}\mathrm{H}_{2} \mathrm{O}_{2}\left(\mu \mathrm{mol} \mathrm{g}{ }^{-1}\right. \\
\text { protein })\end{array}$ & $40.67 \pm 2.21^{\mathrm{a}}$ & $98.56 \pm 7.11^{c}$ & $72.65 \pm 3.77^{b}$ \\
\hline $\begin{array}{c}\text { MDA (nmol mg } \\
\text { protein) }\end{array}$ & $2.12 \pm 0.12^{\mathrm{a}}$ & $3.83 \pm 0.17^{c}$ & $3.19 \pm 0.16^{\mathrm{b}}$ \\
\hline $\begin{array}{c}\mathrm{PC}\left(\mathrm{nmol} \mathrm{mg} \mathrm{m}^{-1}\right. \\
\text { protein) }\end{array}$ & $1.15 \pm 0.06^{\mathrm{a}}$ & $2.58 \pm 0.14^{c}$ & $2.02 \pm 0.11^{\mathrm{b}}$ \\
\hline $\begin{array}{c}\text { GSH }\left(\mu \mathrm{mol} \mathrm{g}{ }^{-1}\right. \\
\text { protein })\end{array}$ & $5.31 \pm 0.33^{c}$ & $2.23 \pm 0.12^{\mathrm{a}}$ & $3.39 \pm 0.16^{\mathrm{b}}$ \\
\hline $\begin{array}{l}\mathrm{SOD}\left(\mathrm{U} \mathrm{mg}^{-1}\right. \\
\text { protein })\end{array}$ & $49.45 \pm 2.77^{c}$ & $12.34 \pm 0.51^{\mathrm{a}}$ & $25.14 \pm 1.31^{\mathrm{b}}$ \\
\hline $\begin{array}{c}\text { CAT }\left(\mathrm{U} \mathrm{mg}^{-1}\right. \\
\text { protein) }\end{array}$ & $6.33 \pm 0.35^{c}$ & $3.31 \pm 0.21^{\mathrm{a}}$ & $4.45 \pm 0.23^{b}$ \\
\hline $\begin{array}{c}\mathrm{GPx}\left(\mathrm{U} \mathrm{mg}^{-1}\right. \\
\text { protein })\end{array}$ & $69.14 \pm 4.26^{c}$ & $36.15 \pm 1.77^{\mathrm{a}}$ & $47.78 \pm 0.25^{\mathrm{b}}$ \\
\hline
\end{tabular}

Values are means \pm S.D. $(n=6)$. Values within the same line having different superscripts are significantly different $(P<0.05)$.
$\mathrm{H}_{2} \mathrm{O}_{2}$, MDA and PC in the erythrocytes of carp.

As presented in Table 4, exposure to $\cdot \mathrm{OH}$ markedly decreased the level of GSH and the activities of SOD, CAT and GPx in carp erythrocytes of the basal group in comparison to those in the untreated basal group $(P<0.05)$. However, the level of GSH and the activities of SOD, CAT and GPx in $\cdot \mathrm{OH}$-treated erythrocytes of carp in the Gln group was higher than that in the basal group $(P<0.05)$ (Table 4$)$, which indicated that dietary Gln effectively inhibited the $\cdot$ OH-induced decreases in the level of GSH and the activities of SOD, CAT and GPX in carp erythrocytes.

\subsection{The effects of Ala, Cit and Pro on the $\cdot \mathrm{OH}$-treated carp erythrocytes}

The effects of Ala, Cit and Pro on PS exposure and DNA fragmentation in the $\cdot \mathrm{OH}$-treated carp erythrocytes were presented in Fig. 2. Compared to the controls, the levels of PS exposure and DNA fragmentation were significantly increased in carp erythrocytes that had been exposed to $\cdot \mathrm{OH}(P<0.05)$. However, when treatment with Ala, Cit and Pro in the $\cdot \mathrm{OH}$-induced carp erythrocytes, the levels of PS exposure and DNA fragmentation were gradually decreased with the increasing concentrations (0.175-1.400 mM) $(P<0.05)$ (Fig. 2). Especially, when treatment with Pro in the $\cdot \mathrm{OH}$-induced carp erythrocytes, the $\mathrm{ID}_{50}$ on the levels of PS exposure and DNA fragmentation were respectively estimated to be 0.88 and $0.93 \mathrm{mM}$ that are the minimum value among amino acids examined so far $(P<0.05)$ (Table 5$)$. The $\mathrm{ID}_{50}$ of Ala on the levels of PS exposure was equivalent to that of Pro treatment $(P<0.05)$ (Table 5). The $\mathrm{ID}_{5}$ of Ala and Pro on PS exposure and DNA fragmentation were less than the level of Ala and Pro in plasma of juvenile Jian $(P<0.05)$ (Tables 1 and 5 ).

The effects of Ala, Cit, Pro and $\mathrm{Ala}_{10} \mathrm{Pro}_{4} \mathrm{Cit}_{1}$ on the levels of Met$\mathrm{Hb}, \mathrm{MDA}$ and $\mathrm{PC}$ in $\cdot \mathrm{OH}$-induced carp erythrocytes were presented in Fig. 3 A, B and C. Compared to the controls, the levels of Met-Hb, MDA and PC were significantly increased in carp erythrocytes exposed to $\mathrm{OH}(P<0.05)$. However, the levels of Met-Hb, MDA and PC were gradually decreased with the increasing concentrations of Ala, Cit, Pro and $\mathrm{Ala}_{10} \mathrm{Pro}_{4} \mathrm{Cit}_{1}(0.175-1.400 \mathrm{mM})$ in the $\cdot \mathrm{OH}$-induced carp erythrocytes $(P<0.05)$ (Fig. $3 \mathrm{~A}$, B and $\mathrm{C})$. Especially, when treatment with $\mathrm{Ala}_{10} \mathrm{Pro}_{4} \mathrm{Cit}_{1}$ in the $\cdot \mathrm{OH}$-induced carp erythrocytes, the $\mathrm{ID}_{50}$ on the levels of Met-Hb, MDA and PC were respectively estimated to be $0.43,0.60$ and $0.51 \mathrm{mM}$ that is the minimum value among Gln's 
(A)
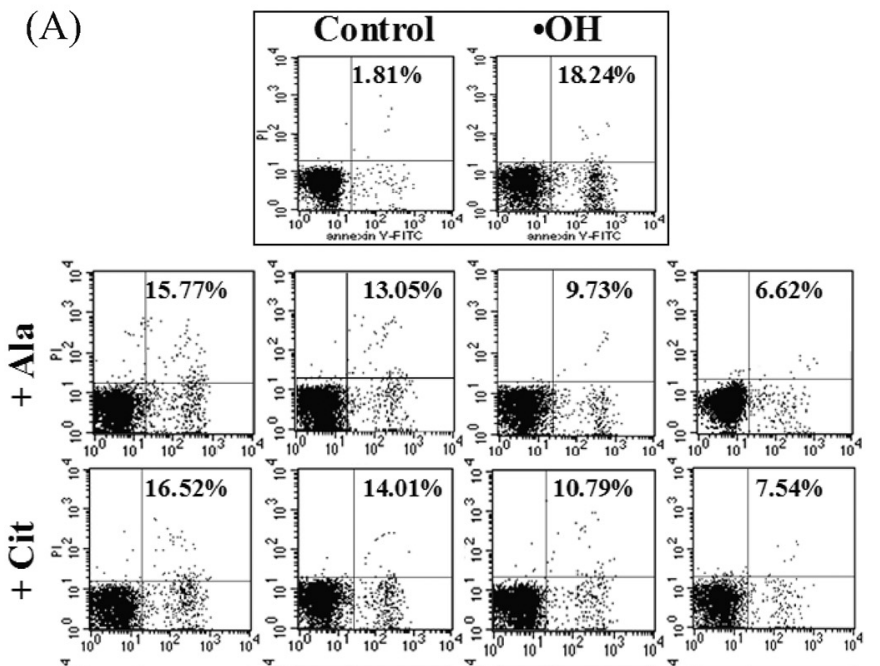

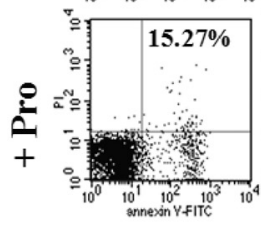

$0.35 \mathrm{mM}$

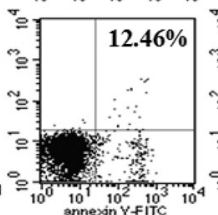

$0.70 \mathrm{mM}$

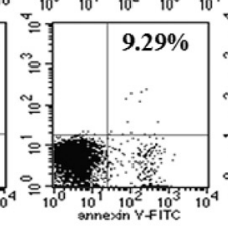

$1.05 \mathrm{mM}$

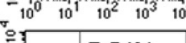

(B)

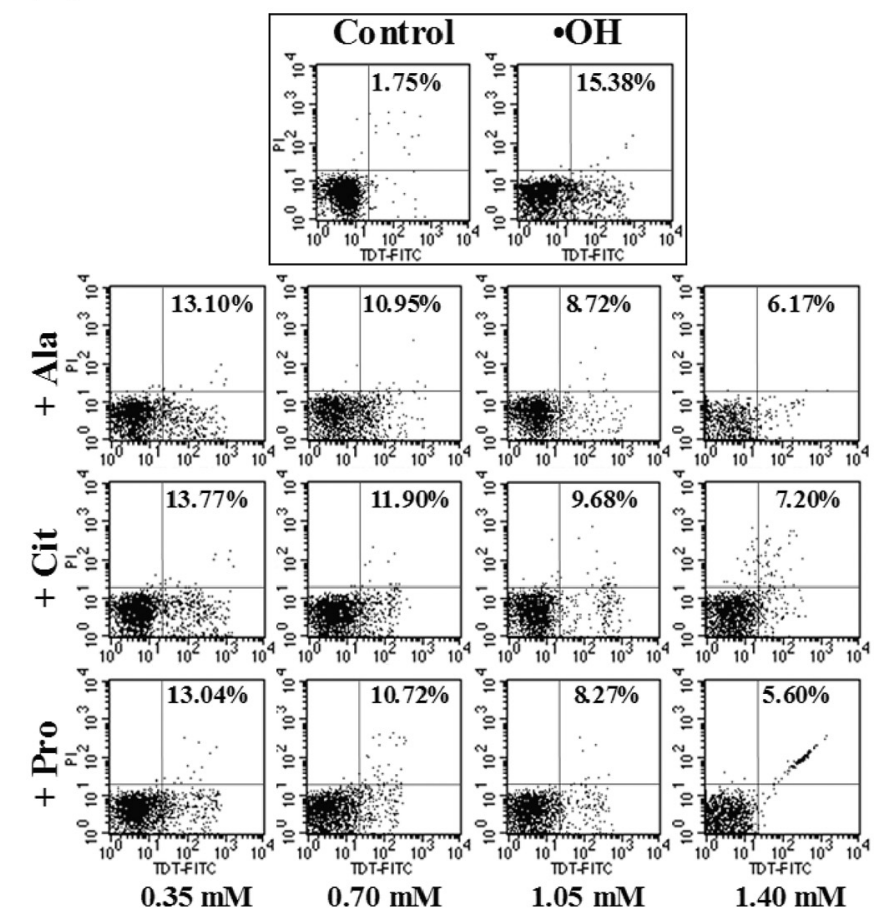

Fig. 2. The effects of Ala, Cit and Pro on the levels of annexin binding (A) and TUNEL (B) in $\cdot \mathrm{OH}$-treated carp erythrocytes. This experiment was repeated three times with similar results achieved.

metabolites examined so far $(P<0.05)$ (Table 6$)$. The $\mathrm{ID}_{50}$ of Cit on the levels of MDA was equivalent to that of $\mathrm{Ala}_{10} \mathrm{Pro}_{4} \mathrm{Cit}_{1}$ treatment $(P<0.05)$ (Table 6). The $\mathrm{ID}_{5}$ of $\mathrm{Ala}_{10} \mathrm{Pro}_{4} \mathrm{Cit}_{1}$ on the levels of Met-Hb and PC were respectively estimated to be 0.054 and $0.069 \mathrm{mM}$, the $\mathrm{ID}_{5}$ of Cit on the levels of MDA were estimated to be $0.053 \mathrm{mM}$ (Table 6), which are the minimum values among compound examined $(P<0.05)$. The $\mathrm{ID}_{5}$ of Ala, Pro and $\mathrm{Ala}_{10} \mathrm{Pro}_{4} \mathrm{Cit}_{1}$ on Met-Hb, MDA and PC and the $\mathrm{ID}_{5}$ of Cit on Met-Hb and MDA were less than the levels of Ala, Cit and Pro in plasma of juvenile Jian $(P<0.05)$ (Tables 1 and 6).

The effects of Ala, Cit, Pro and $\mathrm{Ala}_{10} \mathrm{Pro}_{4} \mathrm{Cit}_{1}$ on the level of GSH and the activities of GR and GST in the $\cdot \mathrm{OH}$-treated carp erythrocytes were presented in Fig. 3 D, E and F. Compared with the control, the level of GSH and the activities of GR and GST were significantly decreased in carp erythrocytes exposed to $\cdot \mathrm{OH}(P<0.05)$. However, the level of GSH and the activities of GR and GST were gradually increased with the increasing concentrations of Ala, Cit, Pro and $\mathrm{Ala}_{10} \mathrm{Pro}_{4} \mathrm{Cit}_{1}$ $(0.175-1.400 \mathrm{mM})$ in the $\cdot \mathrm{OH}$-induced carp erythrocytes $(P<0.05)$ (Fig. 3 D, E and F). Especially, when the erythrocytes were treated with $\mathrm{Ala}_{10} \mathrm{Pro}_{4} \mathrm{Cit}_{1}$ in the presence of $\cdot \mathrm{OH}$, the $\mathrm{ID}_{50}$ on the decreases in the level of GSH and the activities of GR and GST were respectively estimated to be $0.57,1.66$ and $1.12 \mathrm{mM}$ that are the minimum values among Gln's metabolites examined so far $(P<0.05)$ (Table 7). The $\mathrm{ID}_{5}$ of $\mathrm{Ala}_{10} \mathrm{Pro}_{4} \mathrm{Cit}_{1}$ on the $\cdot \mathrm{OH}$-induced decreases in the levels of GSH and the activities of GR and GST were respectively estimated to be 0.049 , 0.040 and $0.073 \mathrm{mM}$, which are the minimum values among compound examined (Table 7) $(P<0.05)$. The $\mathrm{ID}_{5}$ of Pro on the decreases in the level of GSH was equivalent to that of $\mathrm{Ala}_{10} \mathrm{Pro}_{4} \mathrm{Cit}_{1}$ treatment $(P<0.05)$ (Table 7). The $\mathrm{ID}_{5}$ of Ala, Pro and $\mathrm{Ala}_{10} \mathrm{Pro}_{4} \mathrm{Cit}_{1}$ on the decreases in the level of GSH and the activities of GR and GST and the $\mathrm{ID}_{5}$ of Cit on the decreases in the level of GSH and the activities of GST were less than the levels of Ala, Cit and Pro in plasma of juvenile Jian $(P<0.05)$ (Tables 1 and 7$)$.

\section{Discussion}

\subsection{Dietary Gln improved the function of erythrocytes in carp}

The main function of erythrocytes is transport of $\mathrm{O}_{2}$ and mediation of $\mathrm{CO}_{2}$ production in respiration (Cimen, 2008). In erythrocytes, $\mathrm{Hb}$ is the oxygen carrier protein, which can bind $\mathrm{O}_{2}$ to produce oxygenated $\mathrm{Hb}$ that releases $\mathrm{O}_{2}$ in animal tissue (Johnson et al., 2005). In the present study, dietary Gln increased RBC and HbC in blood of carp. The reasons of the increase in $\mathrm{HbC}$ might be that Gln promotes erythrocyte mature in fish. It has been reported that the more mature erythrocytes of carp have greater volumes and higher $\mathrm{Hb}$ content than young ones (Speckner et al., 1989). In this study, dietary Gln increased MCV and MCH in erythrocytes of carp. These results confirmed that dietary Gln could enhance the function of transporting $\mathrm{O}_{2}$ in blood of fish. The oxygenated $\mathrm{Hb}$ can undergo autoxidation to produce $\mathrm{O}_{2} \cdot{ }^{-}$and Met-Hb that does not bind or transport $\mathrm{O}_{2}$ in erythrocytes (Johnson et al., 2005). The dismutation of $\mathrm{O}_{2} \cdot{ }^{-}$generates $\mathrm{H}_{2} \mathrm{O}_{2}$ that can react with heme $\mathrm{Fe}^{2+}$ to produce $\cdot \mathrm{OH}$ ( Li et al., 2016c). These ROS can oxidise cellular components, such as lipids and proteins, leading to drastic changes in protein function, loss of membrane integrity and erythrocyte death (Cimen, 2008). The present results suggested that dietary Gln decreased $\mathrm{O}_{2} \cdot{ }^{-}, \mathrm{H}_{2} \mathrm{O}_{2}$ and Met-Hb levels in erythrocytes of carp. These results revealed that dietary Gln could reduce the generation of ROS in fish erythrocytes. MDA and PC are the products of lipid and proteins oxidation, respectively (Li et al., 2013). This study indicated that dietary Gln decreased the levels of MDA and PC in the erythrocytes of carp. This is in good agreement with the reports that dietary Gln depressed the levels of MDA and PC in tissue of fish (Hu et al., 2015; Zhu et al., 2011). These results demonstrated that dietary Gln prevents the ROS-induced oxidation of lipid and proteins in the erythrocytes of fish.

The inhibition of Gln on the oxidation of cellular components may be closely associated with GSH in fish erythrocytes. In erythrocytes, GSH is not only the major non-enzymatic antioxidant, which can directly scavenge ROS, protecting membrane lipids and spectrin from oxidation that can increase membrane stiffness, but is also an important sulfhydryl groups ( $-\mathrm{SH}$ ) buffer that can maintain the reduced state of -SH in $\mathrm{Hb}$ and enzymes (Cimen, 2008). The present results suggested 
Table 5

The $50 \%$ or $5 \%$ inhibitory dose $\left(\mathrm{ID}_{50}\right.$ or $\mathrm{ID}_{5}$ ) of Ala, Cit and Pro on the levels of annexin binding and TUNEL in the $\cdot \mathrm{OH}-$ treated carp erythrocytes.

\begin{tabular}{|c|c|c|c|c|}
\hline \multirow[t]{2}{*}{ Treatment } & \multicolumn{2}{|c|}{$\mathrm{ID}_{50}(\mathrm{mM})$} & \multicolumn{2}{|c|}{$\mathrm{ID}_{5}(\mathrm{mM})$} \\
\hline & Annexin binding & TUNEL & Annexin binding & TUNEL \\
\hline Ala & $0.96 \pm 0.04^{\mathrm{a}}$ & $1.00 \pm 0.04^{\mathrm{b}}$ & $0.225 \pm 0.015^{\mathrm{b}}$ & $0.195 \pm 0.009^{\mathrm{a}}$ \\
\hline Cit & $1.10 \pm 0.05^{\mathrm{b}}$ & $1.20 \pm 0.04^{\mathrm{c}}$ & $0.277 \pm 0.009^{c}$ & $0.248 \pm 0.012^{b}$ \\
\hline Pro & $0.88 \pm 0.03^{\mathrm{a}}$ & $0.93 \pm 0.03^{\mathrm{a}}$ & $0.199 \pm 0.007^{\mathrm{a}}$ & $0.201 \pm 0.008^{\mathrm{a}}$ \\
\hline
\end{tabular}

Data represent means \pm S.D. of three replicates. Values within the same column with different superscripts are significantly different $(P<0.05)$.

that dietary Gln increased the level of GSH in fish erythrocytes. This was consistent with the reports that dietary Gln raised GSH content in serum, hepatopancreas and muscles of juvenile Hybrid sturgeon (Zhu et al., 2011). The mechanism for the effect of Gln on GSH content may be closely associated with energy metabolism in fish erythrocytes. A majority of adenosine triphosphate (ATP) is generated by anaerobic glycolysis in mature erythrocytes (Cimen, 2008). LDH is an important glycolytic enzyme in fish erythrocytes (Phillips et al., 2000). In this study, dietary Gln increased the activity of LDH in erythrocytes of carp. It has been demonstrated that carp erythrocytes can use Gln as an energy source (Li et al., 2013). ATP or energy can effectively maintain glutathione in the reduced form thereby protecting $-\mathrm{SH}$ of $\mathrm{Hb}$ and erythrocyte membranes from oxidation (Cimen, 2008). Another mechanism may be that Gln is a substrate for GSH biosynthesis (Guerin et al., 2006). A significant portion of ATP is spent in maintaining the activity of $\mathrm{Na}^{+}, \mathrm{K}^{+}$-ATPase that is necessary to preserve the cytoplasmic ionic milieu thus preventing colloidal osmotic lysis (Cimen, 2008). In the present study, dietary Gln enhanced the activity of $\mathrm{Na}^{+}, \mathrm{K}^{+}$ATPase in erythrocytes of carp. This is in good harmony with the report that dietary Gln increased the $\mathrm{Na}^{+}, \mathrm{K}^{+}$-ATPase activity in intestine of carp (Lin and Zhou, 2006). These results above confirmed that dietary Gln could improve the function of erythrocytes in fish.

There may be a positive connection between the effects of Gln on the function of erythrocytes and apoptosis in fish. It has been reported that ROS can trigger erythrocytes apoptosis in human (Cimen, 2008). Our previous studies showed that the mature erythrocytes are more susceptible to ROS-induced apoptosis than young ones of fish (Li et al., 2015). Each day, a small rate of apoptosis erythrocytes are ultimately removed from circulation and replaced by virtually identical numbers of young cells (Cimen, 2008), which have smaller volumes and lower $\mathrm{Hb}$ content than mature erythrocytes in fish (Speckner et al., 1989). No pervious study has addressed that dietary Gln could increase erythrocytes count by haemopoiesis in fish (Rogero et al., 2008). However, the present study displayed that dietary Gln enhanced RBC, MCV and MCH in blood of carp. So, it is possible that dietary Gln inhibits apoptosis of mature erythrocytes in fish. Studies have demonstrated that oral Gln attenuates apoptosis of hepatocytes and neutrophil cells in experimental rat in vivo (Lagranha et al., 2004). Our previous study showed that Gln confers protection against ROS-induced apoptosis in fish erythrocytes in vitro (Li et al., 2013). However, information regarding the effects of Gln on apoptosis of fish erythrocytes is scarce in vivo. Thus, we researched the effects of dietary Gln on the $\cdot \mathrm{OH}$-induced apoptosis in fish erythrocytes.

\subsection{Dietary Gln prevented the $\cdot \mathrm{OH}$-induced apoptosis in fish erythrocytes}

PS exposure and DNA fragmentation are biomarkers of poptosis (Kaptaner and Kankaya, 2013; Li et al., 2016d). In this study, dietary Gln inhibited PS exposure and DNA fragmentation induced by $\cdot \mathrm{OH}$ in carp erythrocytes. These results confirmed that dietary Gln could protect against $\cdot \mathrm{OH}$-induced apoptosis in fish erythrocytes. There may be a positive correlation between the anti-apoptotic effects of dietary Gln and ROS in fish erythrocytes. In the present study, dietary Gln decreased the levels of $\mathrm{O}_{2} \cdot{ }^{-}$and $\mathrm{H}_{2} \mathrm{O}_{2}$ in carp erythrocytes exposed to $\cdot \mathrm{OH}$. This is in accordance with the report that Gln blocked the $\cdot \mathrm{OH}-$ induced increase in the levels of $\mathrm{O}_{2} \cdot{ }^{-}$and $\mathrm{H}_{2} \mathrm{O}_{2}$ in fish erythrocytes in vitro (Li et al., 2013). The anti-apoptotic effects of dietary Gln may be closely associated with the oxidation of cellular components in fish erythrocytes. It has been reported that the oxidative products of lipids and proteins play an important role in the induction of apoptosis in mammalian cells (Li et al., 2016a). This study found that dietary Gln markedly reduced the MDA and PC levels in the $\cdot$ OH-treated carp erythrocytes. This finding is consistent with the report that Gln abrogated the $\cdot \mathrm{OH}$-induced oxidation of lipids and proteins in fish erythrocytes in vitro (Li et al., 2013). These results demonstrated that dietary Gln could protect fish erythrocytes from apoptosis by inhibiting the generation of ROS and the oxidation of cellular components.

The cytosol contains antioxidants that can scavenge intracellular ROS and suppress cellular components oxidation in cells. The key enzymatic antioxidants are SOD, CAT and GPx in erythrocytes (Cimen, 2008; Fan et al., 2015). SOD ensures the enzymatic degradation of $\mathrm{O}_{2} \cdot{ }^{-}$to $\mathrm{H}_{2} \mathrm{O}_{2}$ (Kochhann et al., 2009). CAT detoxifies $\mathrm{H}_{2} \mathrm{O}_{2}$ to $\mathrm{O}_{2}$ and water (Pflugmacher, 2004). GPx carries out the degradation of $\mathrm{H}_{2} \mathrm{O}_{2}$ and lipid hydroperoxides using GSH as substrate (Lin and Shiau, 2009). Studies have demonstrated that SOD and CAT can inhibit apoptosis in human neutrophils (Sulowska et al., 2005). GPx suppresses apoptosis in bovine renal epithelial cell line (Kayanoki et al., 1996). GSH plays an important role in inhibiting apoptosis in mammalian cells (Franco and Cidlowski, 2009). Thus, the anti-apoptosis of dietary Gln may be related to the cytosol antioxidant in fish erythrocytes. In the present study, dietary Gln restored the levels of GSH and the activities of SOD, CAT and GPx in carp erythrocytes, which were depressed following $\cdot \mathrm{OH}$ exposure. This is in good harmony with the report that Gln protect against the $\cdot \mathrm{OH}$-induced decrease in the level of GSH and the activities of SOD, CAT and GPx in fish erythrocytes in vitro (Li et al., 2013). These results revealed that in addition to quenching ROS and preventing the oxidation of cellular components, dietary Gln may affect apoptosis through their elevation of non-enzymatic and enzymatic antioxidant activities.

The effects of Gln on the apoptosis of erythrocytes in vivo may be closely associated with its metabolites in fish. Studies have showed that the most of Gln in diet are converted to Ala, Cit and Pro in the small intestine, which released into the portal circulation in mammals ( $\mathrm{Li}$ et al., 2016a). In this study, dietary Gln raised the levels of Ala, Cit and Pro in plasma of carp. Moreover, our previous report showed that Ala, Cit and Pro protected against apoptosis in fish erythrocytes (Li et al., 2013). However, information regarding the effects of Ala, Cit and Pro at the physiological concentrations on apoptosis is scarce. Thus, we researched the effects of Ala, Cit and Pro on the $\cdot \mathrm{OH}$-induced apoptosis in carp erythrocytes at the physiological concentrations.

\subsection{Protective effects of Ala, Cit and Pro at the physiological concentrations on the $\cdot \mathrm{OH}$-induced apoptosis in carp erythrocytes}

The intracellular GSH are usually kept at high levels through the reduction of oxidised GSH to GSH by GR (Wu et al., 2010). GST plays an antioxidant role by conjugating the cleavage products of lipid peroxides using GSH as substrate (Wen et al., 2015). Both GR and GST have a protective role against apoptosis in human cells (Li et al., 2016c). The present results suggested that Ala and Pro at the physiological 
(A)

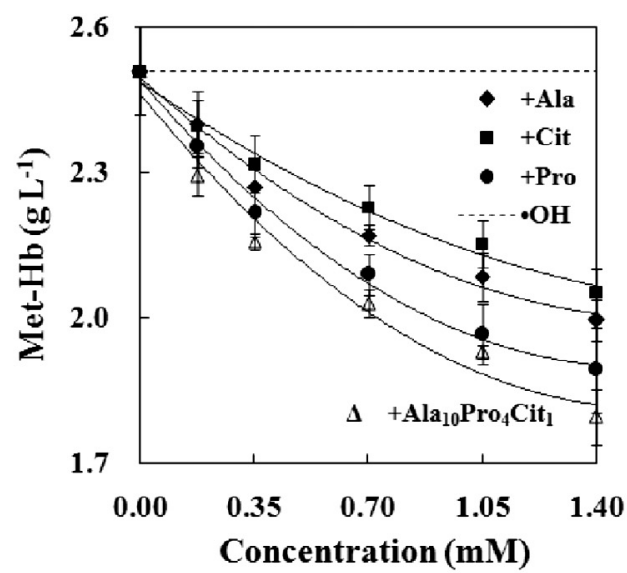

(C)

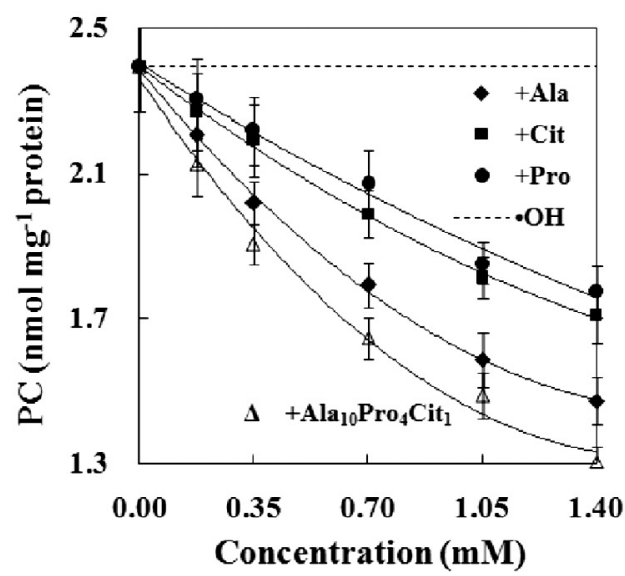

(E)

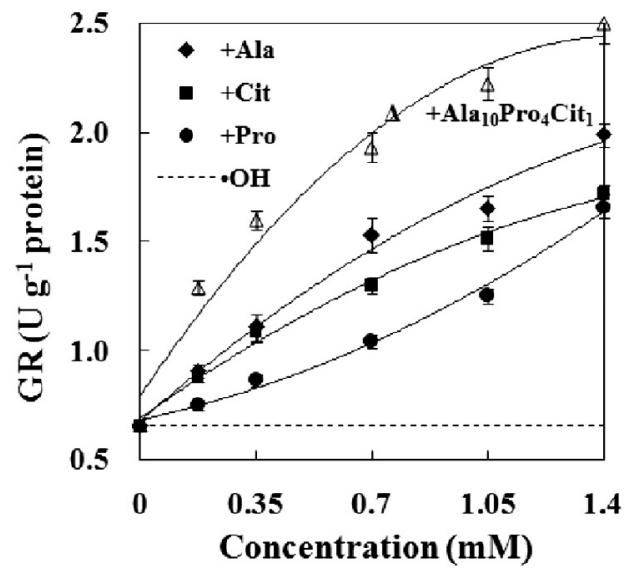

(B)

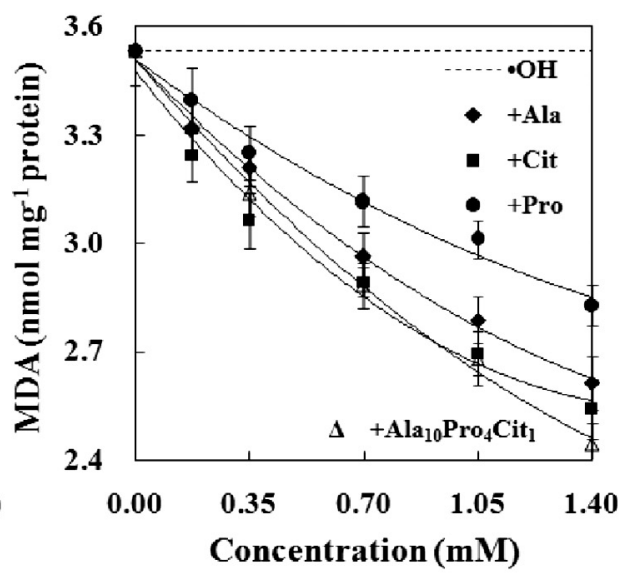

(D)

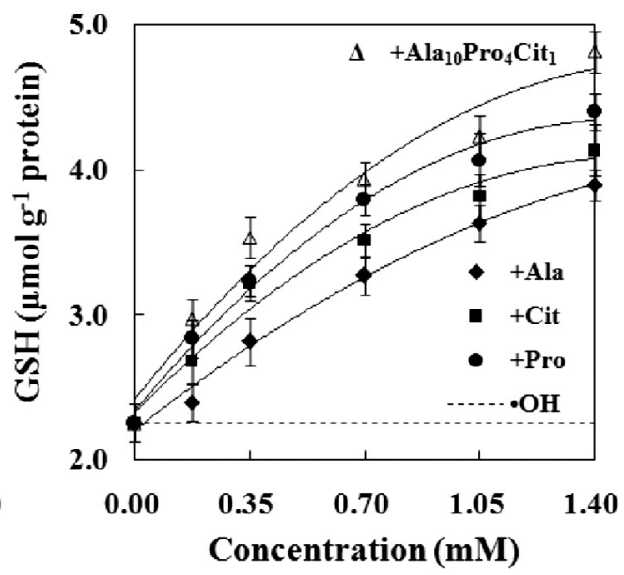

(F)

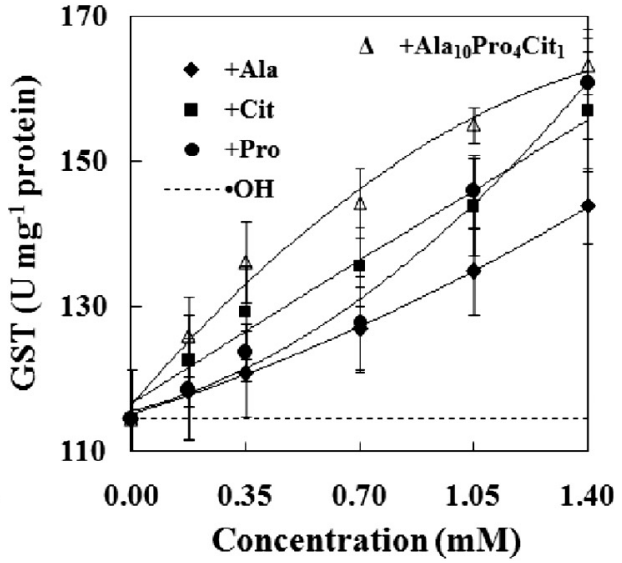

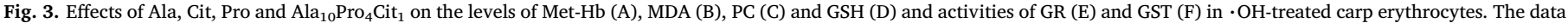
represent the means \pm S.D. of four replicates.

concentrations inhibited PS exposure, DNA fragmentation and the formation of Met-Hb, MDA and PC, and restored the levels of GSH and the activities of GR and GST in - OH-induced carp erythrocytes. Cit at the physiological concentrations prevented the formation of Met-Hb and MDA and maintained GSH level and GST activity in $\cdot \mathrm{OH}$-induced carp erythrocytes. Usually, Ala, Pro and Cit in mixture form are present simultaneously in animal blood (Fujita and Yanaga, 2007). In this study, the combination of Ala, Cit and Pro at the physiological concentrations suppressed the formation of Met-Hb, MDA and PC and restored the levels of GSH and the activities of GR and GST in $\cdot \mathrm{OH}$ induced carp erythrocytes. Furthermore, the combination of Ala, Cit and Pro at the physiological concentrations showed the strongest effects on protecting against the increase in the levels of Met-Hb and PC and decrease in the levels of GSH and the activities of GR and GST in carp erythrocytes. These results confirmed that Ala, Cit or Pro at the physiological concentrations could inhibit apoptosis by preventing the 
Table 6

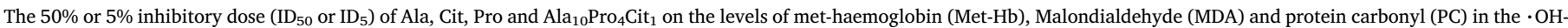
treated carp erythrocytes.

\begin{tabular}{|c|c|c|c|c|c|c|}
\hline \multirow[t]{2}{*}{ Treatment } & \multicolumn{3}{|c|}{$\mathrm{ID}_{50}(\mathrm{mM})$} & \multicolumn{3}{|c|}{$\mathrm{ID}_{5}(\mathrm{mM})$} \\
\hline & Met-Hb & MDA & PC & Met-Hb & MDA & PC \\
\hline Ala & $0.88 \pm 0.05^{c}$ & $0.77 \pm 0.06^{\mathrm{b}}$ & $0.75 \pm 0.05^{\mathrm{b}}$ & $0.072 \pm 0.005^{c}$ & $0.084 \pm 0.006^{\mathrm{b}}$ & $0.085 \pm 0.006^{\mathrm{b}}$ \\
\hline Cit & $1.23 \pm 0.07^{\mathrm{d}}$ & $0.59 \pm 0.04^{\mathrm{a}}$ & $1.33 \pm 0.05^{\mathrm{c}}$ & $0.070 \pm 0.005^{b c}$ & $0.053 \pm 0.003^{\mathrm{a}}$ & $0.126 \pm 0.009^{c}$ \\
\hline Pro & $0.57 \pm 0.04^{\mathrm{b}}$ & $1.36 \pm 0.05^{\mathrm{c}}$ & $1.60 \pm 0.09^{\mathrm{d}}$ & $0.065 \pm 0.005^{\mathrm{b}}$ & $0.094 \pm 0.006^{\mathrm{bc}}$ & $0.150 \pm 0.008^{\mathrm{d}}$ \\
\hline $\mathrm{Ala}_{10} \mathrm{Pro}_{4} \mathrm{Cit}_{1}$ & $0.43 \pm 0.03^{\mathrm{a}}$ & $0.60 \pm 0.04^{\mathrm{a}}$ & $0.51 \pm 0.04^{\mathrm{a}}$ & $0.054 \pm 0.004^{\mathrm{a}}$ & $0.097 \pm 0.008^{c}$ & $0.069 \pm 0.005^{\mathrm{a}}$ \\
\hline
\end{tabular}

Data represent means \pm S.D. of four replicates. Values within the same column with different superscripts are significantly different $(P<0.05)$

Table 7

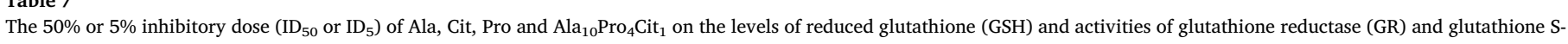
transferase (GST) in the $\cdot$ OH-treated carp erythrocytes.

\begin{tabular}{|c|c|c|c|c|c|c|}
\hline \multirow[t]{2}{*}{ Treatment } & \multicolumn{3}{|c|}{$\mathrm{ID}_{50}(\mathrm{mM})$} & \multicolumn{3}{|c|}{$\mathrm{ID}_{5}(\mathrm{mM})$} \\
\hline & GSH & GR & GST & GSH & GR & GST \\
\hline Ala & $1.33 \pm 0.10^{\mathrm{d}}$ & $3.02 \pm 0.13^{\mathrm{b}}$ & $2.94 \pm 0.18^{c}$ & $0.155 \pm 0.008^{c}$ & $0.140 \pm 0.009^{\mathrm{b}}$ & $0.239 \pm 0.011^{\mathrm{d}}$ \\
\hline Cit & $1.05 \pm 0.09^{c}$ & $5.19 \pm 0.35^{\mathrm{d}}$ & $1.79 \pm 0.11^{\mathrm{b}}$ & $0.063 \pm 0.005^{\mathrm{b}}$ & $0.148 \pm 0.010^{\mathrm{b}}$ & $0.111 \pm 0.008^{\mathrm{b}}$ \\
\hline Pro & $0.77 \pm 0.05^{\mathrm{b}}$ & $4.37 \pm 0.31^{c}$ & $1.57 \pm 0.10^{\mathrm{b}}$ & $0.057 \pm 0.004^{\mathrm{ab}}$ & $0.340 \pm 0.012^{c}$ & $0.189 \pm 0.010^{c}$ \\
\hline $\mathrm{Ala}_{10} \mathrm{Pro}_{4} \mathrm{Cit}_{1}$ & $0.57 \pm 0.04^{\mathrm{a}}$ & $1.66 \pm 0.12^{\mathrm{a}}$ & $1.12 \pm 0.09^{\mathrm{a}}$ & $0.049 \pm 0.004^{\mathrm{a}}$ & $0.040 \pm 0.003^{\mathrm{a}}$ & $0.073 \pm 0.006^{\mathrm{a}}$ \\
\hline
\end{tabular}

Data represent means \pm S.D. of four replicates. Values within the same column with different superscripts are significantly different $(P<0.05)$.

oxidation of cellular components and maintaining GSH antioxidant system in fish erythrocytes.

It has been reported that dietary Gln improves the antioxidant status in serum, hepatopancreas, spleen and muscles of fish (Hu et al., 2015; Zhu et al., 2011). In this study, dietary Gln raised the function and antioxidation and inhibited apoptosis in fish erythrocytes, and increased the levels of Ala, Cit and Pro in fish plasma. Furthermore, Ala, Cit or Pro at the physiological concentrations suppressed apoptosis and the oxidation of cellular components and restored the GSH antioxidant system in fish erythrocytes. The combination of Ala, Cit and Pro at the physiological concentrations showed the strongest effects on preventing the oxidation of cellular components and maintaining GSH antioxidant system in fish erythrocytes. It has been reported that fish erythrocytes may be used as a good model for studying oxidative stress and apoptosis in fish cells (Li et al., 2013). Therefore, the metabolites may be the real executor of beneficial effects in Glnsupplementation fish. This is in good agreement with our previous report that the inhibited effects of Gln on oxidative stress and apoptosis are at least partly dependent on that of its metabolites in mammals ( $\mathrm{Li}$ et al., 2016a).

This study demonstrated that the combination of Ala, Cit and Pro produces a stronger effect than their individual effects on inhibiting the oxidation of cellular components and restored the GSH antioxidant system in fish erythrocytes. However, the reason for this result is unclear. A reason might be the synergetic ability of Ala, Cit and Pro to scavenge $\cdot \mathrm{OH}$. According to the site-specific mechanism, the chelate complex formed by the binding of $\mathrm{Fe}^{2+}$ to the amino group of amino acids can react with $\mathrm{H}_{2} \mathrm{O}_{2}$ to generate a $\cdot \mathrm{OH}$ that will preferentially attack the amino acids moiety before it could escape to the surrounding medium (Stadtman and Levine, 2003). In other words, the metal ioncatalyzed oxidation of amino acids would be a "caged" reaction in which formation of an amino acid- $\mathrm{Fe}^{2+}$ chelate complex is a primary step and in which $\cdot \mathrm{OH}$ formed are not released into solution but react directly with the amino acid (Stadtman, 1991). The combination of Ala, Cit and Pro maybe produce an stronger chelate effects of binding $\mathrm{Fe}^{2+}$ than their individual effects, which would "cage" $\cdot \mathrm{OH}$ outside of erythrocytes. In addition, it has been showed that $\mathrm{Fe}^{2+} / \mathrm{HCO}_{3}{ }^{-} /$amino acid complexes are able to catalyze the disproportion of $\mathrm{H}_{2} \mathrm{O}_{2}$, exhibiting CAT-like antioxidant activity (Stadtman, 1990; Stadtman and Levine, 2003). It has been shown that amino acids are synergistic antioxidants (Marcuse, 1960). Nevertheless, no study has addressed the synergism of amino acids to scavenge $\cdot \mathrm{OH}$. The detailed mechanism needs further research.

\section{Conclusion}

In conclusion, the present results firstly indicated that dietary Gln caused significant increases in Hct, RBC, HbC, MCV and MCH in carp blood. Moreover, dietary Gln caused significant decreases in the levels of $\mathrm{O}_{2} \cdot{ }^{-}, \mathrm{H}_{2} \mathrm{O}_{2}$, Met-Hb, MDA and PC and increases in the level of GSH and the activities of $\mathrm{Na}^{+}, \mathrm{K}^{+}$-ATPase and LDH in carp erythrocytes. These results demonstrated that dietary Gln could improve the function of erythrocytes in fish. Meanwhile, we found that dietary Gln prevented the $\cdot \mathrm{OH}$-induced apoptosis by inhibiting the generation of ROS and the oxidation of cellular components, and restoring the non-enzymatic and enzymatic antioxidant activities in fish erythrocytes. These results revealed that the effects of Gln on the function may be closely associated with apoptosis in fish erythrocytes. Our data suggested for the first time that dietary Gln raised the levels of Ala, Cit and Pro in plasma of carp. Ala, Cit or Pro at the physiological concentrations suppressed apoptosis by preventing the oxidation of cellular components and restoring the GSH antioxidant system in the $\cdot$ OH-induced carp erythrocytes. Moreover, the combination of Ala, Cit and Pro at the physiological concentrations produces a greater protective effect than their individual effects in fish erythrocytes. So, it is reasonable to conclude that the effects of Gln on erythrocytes are at least partly dependent on that of its metabolites in fish. Ala, Cit, Pro and their combination could serve as an antioxidant or apoptosis-inhibitor in fish.

\section{Acknowledgements}

This research was financially supported by the National 973 Project of China (2014CB138600), National Science Foundation of China (30771671, 30871926), National Department Public Benefit Research Foundation (Agriculture) of China (201003020), Outstanding Talents and Innovative Team of Agricultural Scientific Research (Ministry of Agriculture), Science and Technology Support Program of Sichuan Province of China (2014NZ0003), Major Scientific and Technological Achievement Transformation Project of Sichuan Province of China (2012NC0007; 2013NC0045), The Demonstration of Major Scientific 
and Technological Achievement Transformation Project of Sichuan Province of China (2015CC0011) and Natural Science Foundation for Young Scientists of Sichuan Province (2014JQ0007). The authors wish to thank the personnel of these teams for their kind assistance.

\section{References}

Chen, J., Zhou, X.Q., Feng, L., Liu, Y., Jiang, J., 2009. Effects of glutamine on hydrogen peroxide-induced oxidative damage in intestinal epithelial cells of Jian carp (Cyprinus carpio var. Jian). Aquaculture 288, 285-289.

Cimen, M.Y., 2008. Free radical metabolism in human erythrocytes. Clin. Chim. Acta 390, $1-11$.

Darbkin, D.L., 1946. Spectrophotometric studies. XIV the crystallographic and optical properties of the hemoglobin of man in comparison with these of other species. J. Biol. Chem. 164, 703-772.

Franco, R., Cidlowski, J.A., 2009. Apoptosis and glutathione: beyond an antioxidant. Cell Death Differ. 16, 1303-1314.

Fujita, T., Yanaga, K., 2007. Association between glutamine extraction and release of citrulline and glycine by the human small intestine. Life Sci. 80, 1846-1850.

Guerin, P.J., Furtak, T., Eng, K., Gauthier, E.R., 2006. Oxidative stress is not required for the induction of apoptosis upon glutamine starvation of Sp2/0-Ag14 hybridoma cells. Eur. J. Cell Biol. 85, 355-365.

Hu, K., Zhang, J.X., Feng, L., Jiang, W.D., Wu, P., Liu, Y., Jiang, J., Zhou, X.Q., 2015. Effect of dietary glutamine on growth performance, non-specific immunity, expression of cytokine genes, phosphorylation of target of rapamycin (TOR), and anti-oxidative system in spleen and head kidney of Jian carp (Cyprinus carpio var. Jian). Fish Physiol. Biochem. 41, 635-649.

Jiang, J., Zheng, T., Zhou, X.Q., Liu, Y., Feng, L., 2009. Influence of glutamine and vitamin $\mathrm{E}$ on growth and antioxidant capacity of fish enterocytes. Aquac. Nutr. 15, 409-414.

Jiang, W.D., Wu, P., Kuang, S.Y., Liu, Y., Jiang, J., Hu, K., Li, S.H., Tang, L., Feng, L., Zhou, X.Q., 2011. Myo-inositol prevents copper-induced oxidative damage and changes in antioxidant capacity in various organs and the enterocytes of juvenile Jian carp (Cyprinus carpio var. Jian). Aquat. Toxicol. 105, 543-551.

Johnson, R.M., Goyette Jr., G., Ravindranath, Y., Ho, Y.S., 2005. Hemoglobin autoxidation and regulation of endogenous $\mathrm{H}_{2} \mathrm{O}_{2}$ levels in erythrocytes. Free Radic. Biol. Med. 39, 1407-1417.

Kaptaner, B., Kankaya, E., 2013. Analysis of germ cell proliferation, apoptosis, and androgenesis in the Lake Van fish (Chalcalburnus tarichi) during testicular development. Fish Physiol. Biochem. 39, 1665-1679.

Kaptaner, B., Kankaya, E., Ünal, G., 2009. Effects of $17 \alpha$-ethynylestradiol on hepatosomatic index, plasma vitellogenin levels and liver glutathione-s-transferase activity in lake van fish (Chalcalburnus tarichi Pallas, 1811). Fresenius Environ. Bull. 18, 2366-2372.

Kayanoki, Y., Fujii, J., Islam, K.N., Suzuki, K., Kawata, S., Matsuzawa, Y., Taniguchi, N., 1996. The protective role of glutathione peroxidase in apoptosis induced by reactive oxygen species. J. Biochem. 119, 817-822.

Kochhann, D., Pavanato, M.A., Llesuy, S.F., Correa, L.M., Konzen Riffel, A.P., Loro, V.L., Mesko, M.F., Flores, E.M., Dressler, V.L., Baldisserotto, B., 2009. Bioaccumulation and oxidative stress parameters in silver catfish (Rhamdia quelen) exposed to different thorium concentrations. Chemosphere 77, 384-391.

Kulkeaw, K., Sugiyama, D., 2012. Zebrafish erythropoiesis and the utility of fish as models of anemia. Stem Cell Res. Ther. 3, 55.

Lagranha, C.J., Senna, S.M., de Lima, T.M., Silva, É.P.P., Doi, S.Q., Curi, R., Pithon-curi, T.C., 2004. Beneficial effect of glutamine on exercise-induced apoptosis of rat neutrophils. Med. Sci. Sports Exerc. 36, 210-217.

Lang, F., Gulbins, E., Lerche, H., Huber, S.M., Kempe, D.S., Föller, M., 2008. Eryptosis, a window to systemic disease. Cell. Physiol. Biochem. 22, 373-380.

Li, H.T., Feng, L., Jiang, W.D., Liu, Y., Jiang, J., Li, S.H., Zhou, X.Q., 2013. Oxidative stress parameters and anti-apoptotic response to hydroxyl radicals in fish erythrocytes: protective effects of glutamine, alanine, citrulline and proline. Aquat. Toxicol. 126, 169-179.

Li, X.Y., Tang, L., Hu, K., Liu, Y., Jiang, W.D., Jiang, J., Wu, P., Chen, G.F., Li, S.H., Kuang, S.Y., Feng, L., Zhou, X.Q., 2014. Effect of dietary lysine on growth, intestinal enzymes activities and antioxidant status of sub-adult grass carp (Ctenopharyngodon idella). Fish Physiol. Biochem. 40, 659-671.

Li, H.T., Feng, L., Jiang, W.D., Liu, Y., Jiang, J., Zhang, Y.A., Wu, P., Zhou, X.Q., 2015. Ca $(2+)$ and caspases are involved in hydroxyl radical-induced apoptosis in erythrocytes of Jian carp (Cyprinus carpio var. Jian). Fish Physiol. Biochem. 41, 1305-1319.

Li, H.T., Jiang, W.D., Liu, Y., Jiang, J., Zhang, Y.A., Wu, P., Zhao, J., Duan, X.D., Zhou, X.Q., Feng, L., 2016a. The metabolites of glutamine prevent hydroxyl radical-induced apoptosis through inhibiting mitochondria and calcium ion involved pathways in fish erythrocytes. Free Radic. Biol. Med. 92, 126-140.
Li, H.T., Jiang, W.D., Liu, Y., Jiang, J., Zhang, Y.A., Wu, P., Zhao, J., Duan, X.D., Zhou, X.Q., Feng, L., 2016b. Data in the activities of caspases and the levels of reactive oxygen species and cytochrome $c$ in the hydroxylradicals-induced fish erythrocytes treated with alanine, citrulline, proline and their combination. Data in Brief 7, 16-22.

Li, H.T., Zhou, X.Q., Wu, M., Deng, M.L., Wang, C., Hou, J.J., Mou, P.J., 2016c. The cytotoxicity and protective effects of Astragalus membranaceus extracts and butylated hydroxyanisole on hydroxyl radical-induced apoptosis in fish erythrocytes. Anim. Nutr. 2, 376-382.

Li, H.T., Zhou, X.Q., Gao, P., Li, Q.Y., Li, H.S., Huang, R., Wu, M., 2016d. Inhibition of lipid oxidation in foods and feeds and hydroxyl radical-treated fish erythrocytes: a comparative study of Ginkgo biloba leaves extracts and synthetic antioxidants. Anim. Nutr. 2, 234-241.

Lin, Y.H., Shiau, S.Y., 2009. Mutual sparing of dietary requirements for alpha-tocopherol and selenium in grouper, Epinephelus malabaricus. Aquaculture 294, 242-245.

Lin, Y., Zhou, X.Q., 2006. Dietary glutamine supplementation improves structure and function of intestine of juvenile Jian carp (Cyprinus carpio var. Jian). Aquaculture 256, 389-394.

Lin, Y.H., Lin, H.Y., Shiau, S.Y., 2011. Dietary folic acid requirement of grouper, Epinephelus malabaricus, and its effects on non-specific immune responses. Aquaculture 317, 133-137.

Marcuse, R., 1960. Antioxidative effect of amino-acids. Nature 186, 886-887.

Pflugmacher, S., 2004. Promotion of oxidative stress in the aquatic macrophyte Ceratophyllum demersum during biotransformation of the cyanobacterial toxin microcystin-LR. Aquat. Toxicol. 70, 169-178.

Phillips, M.C.L., Moyes, C.D., Tufts, B.L., 2000. The effects of cell ageing on metabolism in rainbow trout (Oncorhynchus mykiss) red blood cells. J. Exp. Biol. 203, 1039-1045.

Rau, M.A., Whitaker, J., Freedman, J.H., Giulio, R.T.D., 2004. Differential susceptibility of fish and rat liver cells to oxidative stress and cytotoxicity upon exposure to prooxidants. Comp. Biochem. Physiol. C 137, 335-342.

Rogero, M.M., Tirapegui, J., Vinolo, M.A.I.R., Borges, M.C., Castro, I.A.D., Pires, I.S.d.O., Borelli, P., 2008. Dietary glutamine supplementation increases the activity of peritoneal macrophages and hemopoiesis in early-weaned mice inoculated with Mycobacterium bovis Bacillus Calmette-Gue' rin. J. Nutr. 138, 1343-1348.

Sevcikova, M., Modra, H., Slaninova, A., Svobodova, Z., 2011. Metals as a cause of oxidative stress in fish a review. Vet. Med. 56, 537-546.

Shiau, S.Y., Su, S.L., 2005. Juvenile tilapia (Oreochromis niloticus $\times$ Oreochromis aureus) requires dietary myo-inositol for maximal growth. Aquaculture 243, 273-277.

Speckner, W., Schindler, J.F., Albers, C., 1989. Age-dependent changes in volume and haemoglobin content of erythrocytes in the carp (Cyprinus carpio L.). J. Exp. Biol. 141, 133-149.

Stadtman, E.R., 1990. Metal ion-catalyzed oxidation of proteins biochemical mechanism and biological consequences. Free Radic. Biol. Med. 9, 315-325.

Stadtman, E.R., 1991. Fenton chemistry: amino acid oxidation. J. Biol. Chem. 266, 17201-17211.

Stadtman, E.R., Levine, R.L., 2003. Free radical-mediated oxidation of free amino acids and amino acid residues in proteins. Amino Acids 25, 207-218.

Sulowska, Z., Majewska, E., Klink, M., Banasik, M., Tchorzewski, H., 2005. Flow cytometric evaluation of human neutrophil apoptosis during nitric oxide generation in vitro: the role of exogenous antioxidants. Mediat. Inflamm. 2005, 81-87.

Surai, P.F., Fisinin, V.I., Karadas, F., 2016. Antioxidant systems in chick embryo development. Part 1. Vitamin E, carotenoids and selenium. Anim. Nutr. 2, 1-11.

Wang, W.F., Mai, K.S., Zhang, W.B., Xu, W., Ai, Q.H., Liufu, Z.G., Li, H.T., 2012. Dietary selenium requirement and its toxicity in juvenile abalone Haliotis discus hannai Ino. Aquaculture 330-333, 42-46.

Wen, J., Jiang, W.D., Feng, L., Kuang, S.Y., Jiang, J., Tang, L., Zhou, X.Q., Liu, Y., 2015. The influence of graded levels of available phosphorus on growth performance, muscle antioxidant and flesh quality of young grass carp (Ctenopharyngodon idella). Anim. Nutr. 1, 77-84.

Wu, C.L., Mai, K.S., Zhang, W.B., Ai, Q.H., Xu, W., Wang, X.J., Ma, H.M., Liufu, Z.G., 2010. Molecular cloning, characterization and mRNA expression of seleniumdependent glutathione peroxidase from abalone Haliotis discus hannai Ino in response to dietary selenium, zinc and iron. Comp. Biochem. Physiol. C 152, 121-132.

Wu, C.L., Zhang, W.B., Mai, K.S., Xu, W., Zhong, X.L., 2011. Effects of dietary zinc on gene expression of antioxidant enzymes and heat shock proteins in hepatopancreas of abalone Haliotis discus hannai. Comp. Biochem. Physiol. C 154, 1-6.

Fan, Z.Y., Xiao, Y., Chen, Y.H., Wu, X., Zhang, G.L., Wang, Q.H., Xie, C.Y., 2015. Effects of catechins on litter size, reproductive performance and antioxidative status in gestating sows. Anim. Nutr. 1, 271-275.

Zhou, Q.C., Zhao, J., Li, P., Wang, H.L., Wang, L.G., 2011. Evaluation of poultry byproduct meal in commercial diets for juvenile cobia (Rachycentron canadum). Aquaculture 322-323, 122-127.

Zhu, Q., Xu, Q.Y., Xu, H., Wang, C.A., Sun, D.J., 2011. Dietary glutamine supplementation improves tissue antioxidant status and serum non-specific immunity of juvenile hybrid sturgeon (Acipenser schrenckii $9 \times$ Huso dauricus ${ }^{7}$ ). J. Appl. Ichthyol. 27, 715-720. 